\title{
Ion release from metal-ceramic alloys in three different media
}

\author{
Lamia MUTLU-SAGESEN¹, Gulfem ERGUN² and Erdem KARABULUT ${ }^{3}$ \\ ${ }^{1}$ Ankara Education and Research Hospital, Ministry of Health, Sukriye mh. 06340, Ulucanlar, Ankara, Turkey \\ ${ }^{2}$ Department of Prosthodontics, Faculty of Dentistry, Gazi University, Biskek cd. 82.sk. No:4 06510, Emek, Ankara, Turkey \\ ${ }^{3}$ Department of Biostatistics, Faculty of Medicine, Hacettepe University, 06100 Altındağ, Ankara, Turkey \\ Corresponding author, Lamia MUTLU-SAGESEN; E-mail: sagesene@isbank.net.tr
}

\begin{abstract}
The aim of this in vitro study was to assess the effect of $\mathrm{pH}$ changes on ion release of metal-ceramic dental casting alloys. Samples from four commercially available alloys (Wirobond C, Wiron 99, Rematitan CP-Ti grade 1, and PontoStar) were prepared and polished. Ion release of alloys subjected to three different $\mathrm{pH}$ media (artificial saliva of $\mathrm{pH} 2.3, \mathrm{pH} 6.5$ and $0.9 \%$ saline solution of $\mathrm{pH} 7.3$ ) for periods of $7,15,30$, and 60 days were assessed by means of atomic absorption spectroscopy. Microscopic changes on surfaces of metallic samples before and after immersion were compared by scanning electron microscopy. ANOVA was used for statistical analysis of results. For all ions, $\mathrm{pH}$ and period interactions were statistically significant: highest amount of ion release occurred after 60 days of immersion regardless of $\mathrm{pH}$ value. For every alloy, ion release results were highest in artificial saliva of $\mathrm{pH} 2.3$ and lowest in $0.9 \%$ saline solution. It was concluded that ion release from alloys was $\mathrm{pH}$-dependent.
\end{abstract}

Keywords: Metal-ceramic alloys, Ion release, Corrosion, pH changes

\section{INTRODUCTION}

Biocompatibility and corrosion resistance of metalceramic alloys are closely interconnected. The toxicity of metal-ceramic alloys depends on various aspects of the metal ions released due to corrosion: quality and quantity of released ions, eventual synergistic or antagonistic effects of released ions, and the length of time they remain in contact with organic tissues ${ }^{1)}$. Ions released during corrosion may be detectable by the patient as a shock that can be disconcerting and even debilitating. Released metallic components may also cause an undesirable metallic taste. Given these unpleasant circumstances, the patient may request for the restoration to be removed.

Many factors contribute to the corrosion of metallic restorations - from inherent properties of the metal used to the environmental factors in the oral cavity. Factors inherent in the metal used include its microstructure, chemical composition, construction technique, and even its galvanic contacts with other existing metallic restorations. On the environmental factors, the oral cavity is a conducive medium for corrosion. Factors that may initiate corrosion include the quantity, quality, and $\mathrm{pH}$ value of secreted saliva (which are affected by the diet and intake of medicines or drugs), intake of organic acids commonly found in foods and beverages (such as lactic, acetic, malic, oxalic, tartaric, and carbonic acids), temperature fluctuations due to food and drink intake, and accumulation of dental plaque (formed by a combination of acids, bacteria, saliva, and food remnants).

Many studies have reported on the release of metallic ions from high-noble, noble, and base dental casting alloys under differing $\mathrm{pH}$ conditions which simulated the oral cavity ${ }^{2,3)}$. A low $\mathrm{pH}$ environment (i.e., acidic conditions) increases the release of metallic ions from dental alloys. This effect is especially pronounced for nickel (Ni)-based alloys ${ }^{4,5)}$. Dental plaque often adheres to dental alloys and creates a low $\mathrm{pH}$ environment locally. This condition promotes the corrosion of dental alloys, thereby causing concern about the biocompatibility of dental alloys ${ }^{6)}$.

The corrosion resistance of an alloy is of fundamental importance to its biocompatibility. The release of ions from the alloy is nearly always necessary for adverse biologic effects such as toxicity, allergy, or mutagenicity6). Elevated levels of corrosion products released in the oral biological environment may cause pathological reactions in the gastrointestinal system or surrounding tissues ${ }^{7}$. Hence, from biocompatibility standpoint, the most relevant measure of corrosion is identifying and quantifying the ions that are released. Elements such as beryllium (Be), cadmium (Cd), cobalt (Co), chromium $(\mathrm{Cr})$, copper $(\mathrm{Cu})$, iron $(\mathrm{Fe})$, nickel $(\mathrm{Ni})$, palladium $(\mathrm{Pd})$, and vanadium (V) are known to be toxic, allergic, or mutagenic, and they should be used in lower ratios in dental alloys ${ }^{6)}$.

Several studies have measured the release of metallic ions from dental alloys of different alloy compositions $^{1,4-6,8-10)}$. For many Ni-based dental casting alloys, Ni was the main element released while other major elements ( $\mathrm{Cr}$ and molybdenum (Mo)), which are considered less toxic, were released at much lower concentrations $^{8}$. In commercial alloys, the compositions of $\mathrm{Cr}$ and Mo range from 11 to $25 \mathrm{wt} \%$ and 0 to $10 \mathrm{wt} \%$ respectively. In a recently published study ${ }^{9}$, it was reported that the total amount of $\mathrm{Cr}$ and Mo within the alloys proved to be of greater influence on corrosion resistance. Alloys that contained lower amounts of $\mathrm{Cr}$ and Mo were reportedly more susceptible to corrosion ${ }^{5,11)}$. A higher amount of chromium (25 wt\%) would result in 
superior corrosion resistance, and this was associated with a more uniform distribution of $\mathrm{Cr}$ in the alloy microstructure $^{11)}$. Conversely, if $\mathrm{Cr}$ content was less than 16-20 wt\%, Ni release increased under all conditions (i.e., both acidic and alkaline $)^{12)}$.

Noble metals are known to be resistant to corrosion. Studies have shown that dental alloys which contained less than $50 \%$ of noble metals exhibited tarnish and corrosion $^{2,13)}$. Therefore, biological risks can be kept to a minimum with the use of high-noble and noble alloys because ion release from these alloys is lower ${ }^{1,2,10,13-15)}$. Nonetheless, there were conflicting reports on ion release behavior from noble alloys in low $\mathrm{pH}$ conditions, which could be attributed to differences of the environment surrounding the tested alloys ${ }^{12)}$. On one hand, it was reported that low $\mathrm{pH}$ caused ion release from $\mathrm{Au}$ alloy to increase; on the other hand, it was also reported that noble alloys were not significantly affected by a low $\mathrm{pH}^{10,12)}$.

Titanium (Ti) and its alloys have become one of the backbone materials for many applications today because of their combination of high strength-to-weight ratio, excellent mechanical properties, and corrosion resistance. Moreover, because of its high reactivity, a surface oxide layer is formed during the casting and soldering of pure Ti. It is widely reported that the excellent biocompatibility of $\mathrm{Ti}$ and its alloys is closely related to the surface oxide layer. In dentistry, Ti is used for crowns and bridges, dental implants, and denture frameworks because of its excellent biocompatibility. Although Ti and its alloys are hypoallergenic and possess many of the clinically favored properties of type III and type IV Au dental alloys, their use is largely limited by their relatively high $\operatorname{cost}^{16)}$.

Ion release from dental alloys has been evaluated mainly by in vitro studies using these methods: cell culture media ${ }^{1,8,15,17)}$, galvanism ${ }^{18)}$, electrolyte baths ${ }^{19)}$, evaluation of the influence of oral proteins on corrosion behavior $^{2,20)}$, exposure to different $\mathrm{pH}$ levels ${ }^{2,3,5,10,20,21)}$, use of different surface treatments to cast alloys ${ }^{9,13)}$, and power toothbrushing with toothpastes of different abrasivities $^{22)}$. In general, a static system is the most frequently used method to monitor the elements released from dental casting alloys. To measure even a low corrosion rate, in vitro electrochemical techniques have proved to be sufficiently sensitive to fulfill this task; moreover, they are quick and convenient and are now used by many researchers ${ }^{7)}$. There are two types of electrochemical techniques. The first involves immersion testing with analytical determination of the quantity of released metal ions by atomic absorption spectroscopy (AAS) or inductively coupled plasma spectroscopy (ICPS). The second involves potentiodynamic and potentiostatic polarization measurements to evaluate corrosion behavior.

To date, only a few studies have investigated the effect of $\mathrm{pH}$ on ion release from high-noble alloys and $\mathrm{Ti}$ alloys. The aim of this study was to evaluate the release of ions from four commercially available dental casting alloys in three different $\mathrm{pH}$ media - artificial saliva of $\mathrm{pH} 2.3$ and $\mathrm{pH} 6.5$ and $0.9 \%$ saline solution of $\mathrm{pH} 7.3-$ for a period of 60 days. A Co-Cr based alloy, a Ni-Cr-based alloy, a Ti-based alloy, and a high-Au alloy were selected for this study. The corrosion products, namely the released ions, were identified and quantified using AAS. Microscopic changes on the surfaces of the alloy samples were observed using scanning electron microscopy (SEM) before and after immersion in different $\mathrm{pH}$ media.

\section{MATERIALS AND METHODS}

\section{Preparation of alloy samples}

Four commercially available metal-ceramic dental casting alloys representing different compositions were selected for this study (Table 1): a Co-Cr-based alloy (Wirobond C, Bego, Bremen, Germany; WBC), a Ni-Cr-based alloy (Wiron 99, Bego, W99), a Ti-based alloy (Rematitan CP-Ti grade 1, Dentaurum, Pforzheim, Germany; RTI), and a high-Au alloy (PontoStar, Bego; PSR).

Carried out as per the manufacturers' recommendations, WBC, W99, and PSR alloys were cast into disks of $3 \mathrm{~mm}$ diameter and $2 \mathrm{~mm}$ thickness $(n=8$ per alloy) and polished. For RTI alloy, disk samples of

Table 1 Metal-ceramic alloys assessed in the study

\begin{tabular}{|c|c|c|c|c|}
\hline Material/Product name & Code & Manufacturer & Lot number & Composition (wt\%) \\
\hline $\begin{array}{l}\text { Co-Cr-Mo-based alloy } \\
\text { Wirobond C } \\
\text { (color: white) }\end{array}$ & WBC & Bego-Germany & 1967 & $\begin{array}{l}61 \mathrm{Co}, 26 \mathrm{Cr}, 6 \mathrm{Mo}, 5 \mathrm{~W}, 1 \mathrm{Si}, 0.5 \\
\text { Fe, } 0.5 \mathrm{Ce}, 0.02 \mathrm{C}\end{array}$ \\
\hline $\begin{array}{l}\text { Ni-Cr-Mo-based alloy } \\
\text { Wiron } 99 \\
\text { (type } 4 \text {, color: white) }\end{array}$ & W99 & Bego-Germany & 9868 & $\begin{array}{l}65 \mathrm{Ni}, 22.5 \mathrm{Cr}, 9.5 \mathrm{Mo}, 1 \mathrm{Si}, 1 \mathrm{Nb} \\
0.5 \mathrm{Fe}, 0.5 \mathrm{C}\end{array}$ \\
\hline $\begin{array}{l}\text { Ti-based alloy } \\
\text { Rematitan CP-Ti grade } 1\end{array}$ & $\mathrm{RTI}$ & $\begin{array}{l}\text { Dentaurum- } \\
\text { Germany }\end{array}$ & 148 & $\begin{array}{l}99.49 \mathrm{Ti}, 0.15 \mathrm{Fe}, 0.12 \mathrm{O}, 0.06 \mathrm{C} \\
0.05 \mathrm{~N}\end{array}$ \\
\hline $\begin{array}{l}\text { High-Au alloy } \\
\text { PontoStar } \\
\text { (type hard } 3 \text {, color: gold yellow) }\end{array}$ & PSR & Bego-Germany & 941901 & $85 \mathrm{Au}, 11.6 \mathrm{Pt}, 1.5 \mathrm{In}, 1.3 \mathrm{Rh}, 0.6 \mathrm{Pd}$ \\
\hline
\end{tabular}


the same dimensions $(n=8)$ were prepared and polished in the Metallurgy Laboratory of Research and Development Department of Dentaurum. To ensure sample homogeneity, the diameter $(\mathrm{R}=3 \pm 0.1 \mathrm{~mm})$ and height $(\mathrm{h}=2 \pm 0.1 \mathrm{~mm})$ of each sample were checked using a caliper compass. With a precision scale, sample weights were determined as follows: $0.355 \pm 0.050 \mathrm{~g}$ for WBC, $0.350 \pm 0.050 \mathrm{~g}$ for W99, $0.180 \pm 0.020 \mathrm{~g}$ for RTI, and $0.330 \pm 0.030 \mathrm{~g}$ for PSR.

\section{Immersion solutions}

Three test solutions (Table 2) were used in this study for immersion testing before AAS and SEM analyses: artificial saliva with pH 2.3 (AS-LA) and pH 6.5 (AS-SS), and $0.9 \%$ saline solution at $\mathrm{pH} 7.3$ (SS).

1. Artificial saliva media with $\mathrm{pH} 2.3$ and $\mathrm{pH} 6.5$

To prepare artificial saliva, $7.69 \mathrm{~g}$ of $\mathrm{K}_{2} \mathrm{HPO}_{4}, 2.46 \mathrm{~g}$ of $\mathrm{KH}_{2} \mathrm{PO}_{4}, 5.3 \mathrm{~g}$ of $\mathrm{NaCl}$, and $9.3 \mathrm{~g}$ of $\mathrm{KCl}$ were added to $1,000 \mathrm{~mL}$ of distilled water. The prepared solution was divided into two balloon glasses equally.

According to ISO 10271:2001 Standard ${ }^{23)}$, the pH of solution used for immersion testing should be acidic (2.3 \pm 0.1$)$. Moreover, dental plaque produces a reduced $\mathrm{pH}$, making it more relevant to test the effects of acids on dental alloys to address the biocompatibility concerns ${ }^{6}$. Average salivary $\mathrm{pH}$ is 6.7. The $\mathrm{pH}$ of artificial saliva was lowered to 2.3 by adding lactic acid (to obtain AS-LA) and to 6.5 by adding $\mathrm{NaOH}$ (to obtain AS-SS). After the $\mathrm{pH}$ values were adjusted to their desired levels using lactic acid and $\mathrm{NaOH}$, they were measured using a $\mathrm{pH}$ meter (Philips PW 9422). The AS-LA solution was used to test the extreme conditions of short-term $\mathrm{pH}$ variances. Examples of causes of short-term $\mathrm{pH}$ variances include the intake of acidic beverages. The AS-SS solution was used to test $\mathrm{pH}$ variances arising from long-term exposure, such as that of daily saliva.

2. Saline solution with $\mathrm{pH} 7.3$

$0.9 \% \mathrm{NaCl}$ saline solution with $\mathrm{pH} 7.3$ was coded as SS solution in this study. Its chloride $(\mathrm{Cl})$ concentration was very similar to that of human body fluid. It was thus used as a control.

\section{Immersion test}

After $10 \mathrm{~mL}$ of each test solution was poured into coded polypropylene test tubes, they were mixed and homogenized using a vibrator (NM-110 Vortex). Metal samples were coded, washed in distilled water and alcohol, and then immersed in polypropylene tubes containing the immersion solutions. To monitor the release of metallic ions into the immersion solutions in polypropylene tubes, control test tubes containing immersion solutions only were also prepared. All test tubes were incubated at $37^{\circ} \mathrm{C}$. No $\mathrm{pH}$ measurements were carried out during immersion test procedures to avoid disturbing the ion release process.

There is a close link between the conditions under which experiments are performed and the eventual experimental results. For this reason, special care was exercised when preparing the immersion solutions, and in particular the composition of the immersion solution ${ }^{24)}$.

\section{Atomic absorption spectroscopy}

After 7, 15, 30, and 60 days of immersion, the quantities of metallic ions released were measured by AAS. This technique is able to quantify metal ions in very dilute concentrations in the range of parts per billions (ng/mL). For a few seconds every day, a vortex was used to mix the immersion solutions in all the test tubes. After

Table 2 Artificially prepared solutions used for immersion

\begin{tabular}{llll}
\hline Solution & Code & $\mathrm{pH}$ & \multicolumn{1}{c}{ Composition (mL) } \\
\hline Artificial saliva + lactic acid & AS-LA & 2.3 & $12 \mathrm{~mL}$ lactic acid to $500 \mathrm{~mL}$ solution \\
Artificial saliva $+0.9 \% \mathrm{NaCl}$ & AS-SS & 6.5 & $(0.126 \mathrm{~g} \mathrm{NaOH}+0.9 \% \mathrm{NaCl})$ to $500 \mathrm{~mL}$ solution \\
Saline solution $(0.9 \% \mathrm{NaCl})$ & SS & 7.3 & $0.9 \% \mathrm{NaCl}$ \\
\hline
\end{tabular}

Table 3 Atomic absorption spectroscopy parameters used for the elements

\begin{tabular}{lcccc}
\hline Element & Wavelength $(\mathrm{nm})$ & Slit Width $(\mathrm{nm})$ & Lamp Current $(\mathrm{mA})$ & Flame* \\
\hline $\mathrm{Au}$ & 242.8 & 0.7 & 4 & - \\
$\mathrm{Co}$ & 240.7 & 0.2 & 7 & - \\
$\mathrm{Cr}$ & 357.9 & 0.2 & 5 & $\mathrm{~A} / \mathrm{A}$ \\
$\mathrm{Fe}$ & 248.3 & 0.2 & 5 & - \\
$\mathrm{In}$ & 303.9 & 0.5 & 7 & - \\
$\mathrm{Mo}$ & 313.3 & 0.5 & 4 & - \\
$\mathrm{Ni}$ & 341.5 & 0.2 & & - \\
$\mathrm{Pt}$ & 265.9 & 0.2 & 10 & - \\
$\mathrm{Ti}$ & 365.4 & 0.2 & 20 & - \\
\hline
\end{tabular}

\footnotetext{
* $\mathrm{A} / \mathrm{A}=$ air/acetylene
} 
mixing, $2 \mathrm{~mL}$ of immersion solution was removed from each test tube and $\mathrm{Au}, \mathrm{Pt}, \mathrm{In}, \mathrm{Cr}, \mathrm{Co}, \mathrm{Mo}, \mathrm{Fe}, \mathrm{Ti}$, and $\mathrm{Ni}$ ion levels were measured using an AAS (Varian 30/40, Varian Techtron Pty Ltd., Mulgrave, Victoria, Australia).

AAS uses absorption of light to measure the concentration of atoms in the gas phase. Ions or atoms in a sample must be dissolved and vaporized in a hightemperature source such as a flame or graphite furnace. Flame AA can analyze solutions only, while graphite furnace AA can accept solutions, slurries, or solid samples. Flame AA needs a slot-type burner to increase the path length to increase the total absorbance. Sample solutions are usually aspirated with the gas flow into a nebulizing/mixing chamber to form small droplets before entering the flame. Compared to flame AA, the graphite furnace wields several advantages. It is a more efficient atomizer than a flame and it can directly accept very tiny absolute quantities of samples. After a sample is placed directly in the graphite furnace, the furnace is electrically heated in several steps to dry the sample, ash organic matter, and vaporize the analyte atoms.

In this study, Fe ions were measured using flame AA method, while the other ions (Au, Pt, In, Cr, Co, Mo, Ti, and $\mathrm{Ni}$ ions) were measured using the graphite furnace AA method. Table 3 lists the specific parameters used for the detection of each element. Analysis for each sample was carried out in triplicate and the value obtained by calculating the average of three experiments.

\section{Scanning electron microscopy}

The surface appearances of the polished disk samples before immersion and the microscopic changes that occurred after 60 days of immersion were examined by SEM (JSM 6400, Jeol, Tokyo, Japan). Samples randomly selected from each group were washed under distilled water and observed under these SEM settings: $20 \mathrm{kV}$ accelerating potential and $\times 1,000$ magnification.

\section{Statistical analysis and comparison of results}

Statistical analysis for periods was performed using one-way ANOVA. Repeated-measures ANOVA and independent t-test were also used to evaluate the effect of immersion period. To make comparisons with previous studies, percent compositions of metal ion corrosion products released from the metal-ceramic alloys were also calculated.

Ion release concentrations obtained from atomic absorption measurements were expressed in $\mathrm{ng} / \mathrm{mL}$. According to ISO 8891:1998 ${ }^{25}$ ), the maximum quantity of released corrosion products was allowed to be $100 \mu \mathrm{g} / \mathrm{cm}^{2}$ per week. To calculate ion release in $\mu \mathrm{g} / \mathrm{cm}^{2}$ for each metal-ceramic alloy in three different media for a period of 7 days, amounts in $\mathrm{ng} / \mathrm{mL}$ were converted to $\mu \mathrm{g}$ of mass released from the alloy per square centimeter of alloy surface exposed to the immersion solution for each ion.

\section{RESULTS}

When a dental alloy is placed in the oral environment, it is subjected to chemical attacks and consequently releases metallic ions into the oral environment. In this study, three artificially prepared solutions mimicked the $\mathrm{pH}$ variances routinely encountered in the oral environment. Four dental alloys representing different compositions were immersed in these solutions for a 60-day period. AAS was used to measure the concentration levels of different metallic ions released from the dental alloys into the immersion solutions. No alloy samples were removed from the immersion solutions throughout the entire 60-day period; only solution samples were removed from the test tubes at every designated time period.

\section{$A A S$ analysis}

Figures 1-4 show the results of released ions from the four dental alloys in three different media over a 60-day

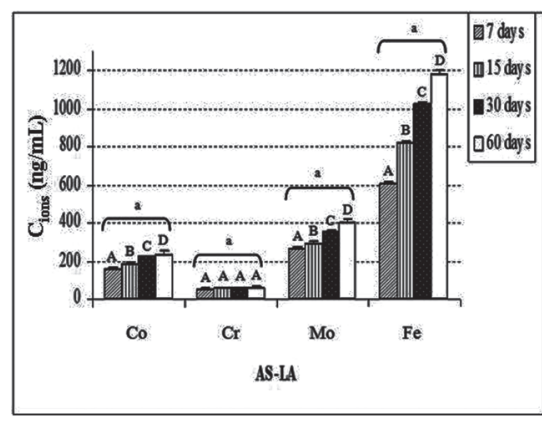

(a)

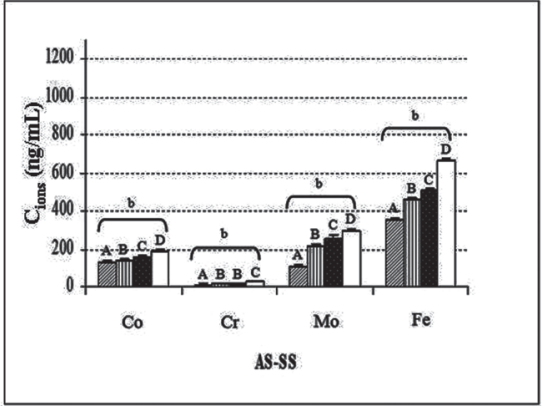

(b)

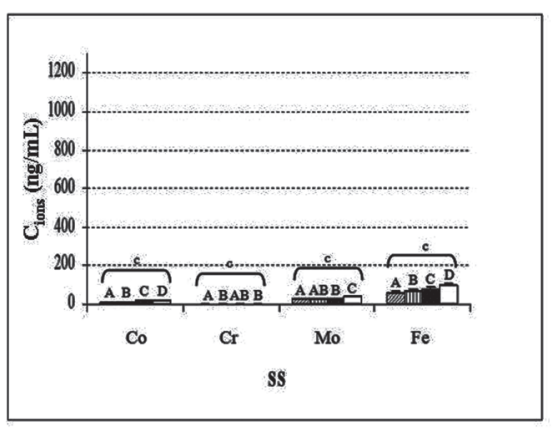

(c)

Fig. 1 Release amounts of Co, Cr, Mo, and Fe elements from WBC alloy in: (a) AS-LA solution; (b) AS-SS solution; and (c) SS solution. Error bar indicates one standard deviation of $n=8$. A, B, C, D: Capital letters indicate statistically significant differences in release amount of an immersion group among the periods $(p<0.05)$. a, b, c: Small letters indicate statistically significant differences among immersion solutions in each time period $(p<0.05)$. 


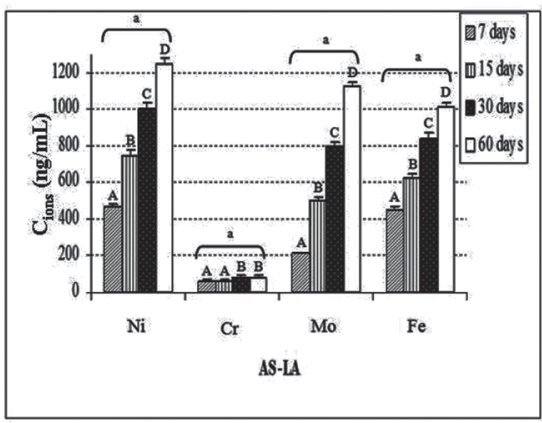

(a)

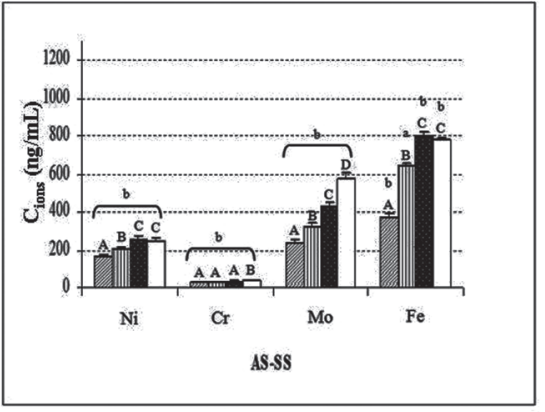

(b)

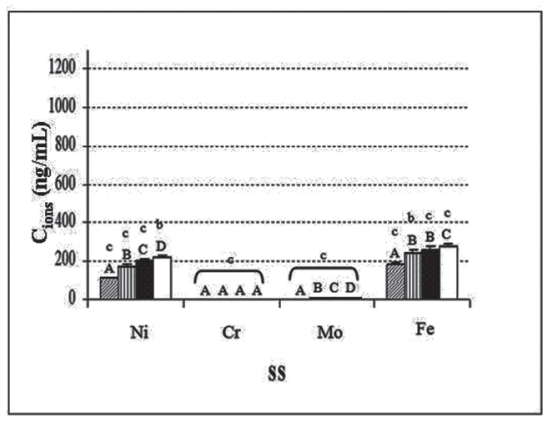

(c)

Fig. 2 Release amounts of Ni, Cr, Mo, and Fe elements from W99 alloy in: (a) AS-LA solution; (b) AS-SS solution; and (c) SS solution. Error bar indicates one standard deviation of $n=8$. A, B, C, D: Capital letters indicate statistically significant differences in release amount of an immersion group among the periods $(p<0.05)$. a, b, c: Small letters indicate statistically significant differences among immersion solutions in each time period $(p<0.05)$.

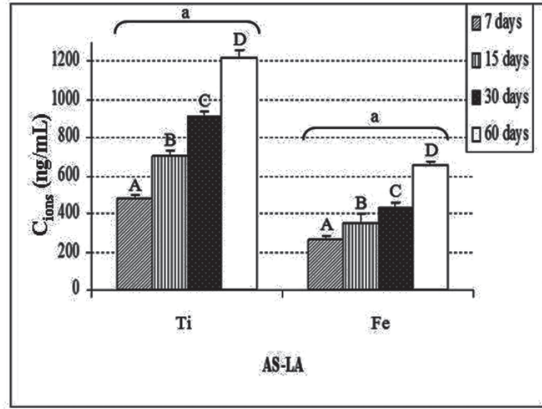

(a)

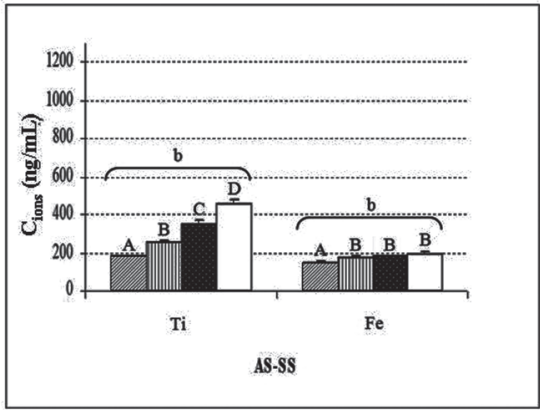

(b)

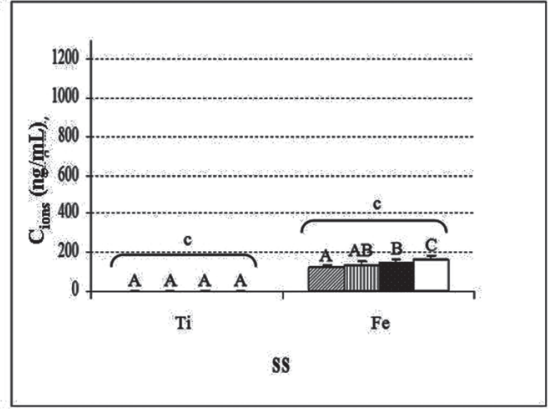

(c)

Fig. 3 Releases amounts of Ti and Fe elements from RTI alloy in: (a) AS-LA solution; (b) AS-SS solution; and (c) SS solution. Error bar indicates one standard deviation of $n=8$. A, B, C, D: Capital letters indicate statistically significant differences in release amount of an immersion group among the period $(p<0.05)$. a, b, c: Small letters indicate statistically significant differences among immersion solutions in each time period $(p<0.05)$.

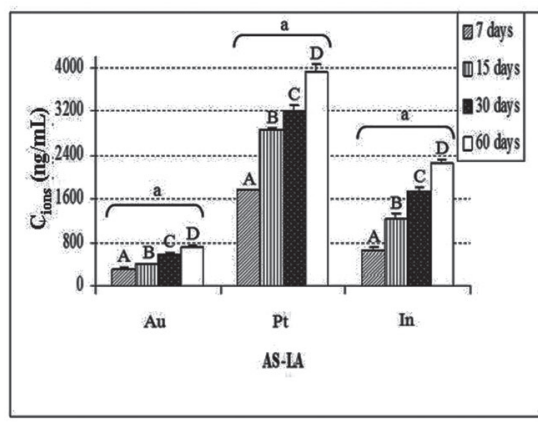

(a)

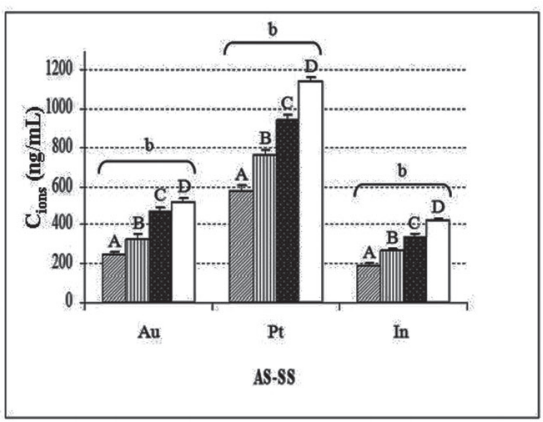

(b)

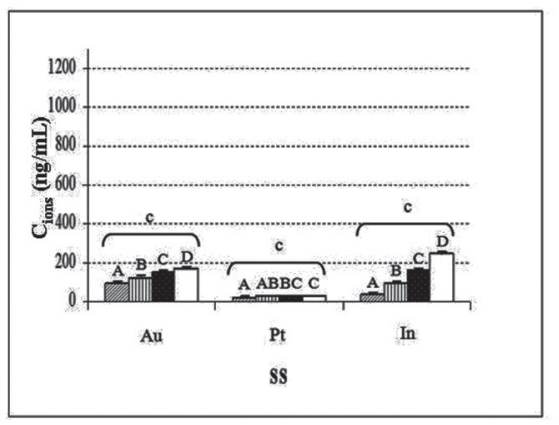

(c)

Fig. 4 Release amounts of Au, Pt, and In elements from PSR alloy in: (a) AS-LA solution; (b) AS-SS solution; and (c) SS solution. Error bar indicates one standard deviation of $n=8$. A, B, C, D: Capital letters indicate statistically significant differences in release amount of an immersion group among the periods $(p<0.05)$. a, b, c: Small letters indicate statistically significant differences among immersion solutions in each time period $(p<0.05)$. 
period. For all the dental alloys in all the three media, ion concentration of each element increased toward the 60th day. This meant that the metallic ion release processes increased with length of immersion period, except for Ni ions of W99 alloy in AS-SS solution.

Statistical analysis revealed statistically significant interactions between $\mathrm{pH}$ of immersion medium and immersion period. For every immersion group, repeatedmeasures ANOVA was performed to evaluate the effect of immersion period. Different capital letters (A, B, C, or D) were shown in Figs. 1-4 to indicate presence of statistically significant differences $(p<0.05)$ in ion release amount among the immersion periods for each immersion group. However, for all the periods, differences among the immersion groups were examined by one-way ANOVA and indicated with small letters ( $a, b$, or c) for presence of statistically significant differences $(p<0.05)$ in Figs. 1-4.

Based on AAS measurements, Table 4 presents the percent compositions (wt\%) of metal ion corrosion products released from each metal-ceramic alloy in each immersion medium after 60 days.

Table 4 Percent compositions (wt\%) of metal ion corrosion products released from metal-ceramic alloys based on 60-day atomic absorption measurements in three different media

\begin{tabular}{|c|c|c|c|c|c|c|c|c|c|c|}
\hline & Co & $\mathrm{Cr}$ & Mo & $\mathrm{Fe}$ & $\mathrm{Ni}$ & $\mathrm{Ti}$ & $\mathrm{Au}$ & $\mathrm{Pt}$ & In & TOTAL \\
\hline Alloys & \multicolumn{10}{|c|}{ in AS-LA } \\
\hline WBC & 0.66 & 0.16 & 1.12 & 3.32 & & & & & & 5.26 \\
\hline W99 & & 0.24 & 3.22 & 2.90 & 3.56 & & & & & 9.92 \\
\hline RTI & & & & 3.62 & & 6.76 & & & & 10.38 \\
\hline PSR & & & & & & & 2.18 & 11.92 & 6.76 & 20.86 \\
\hline Alloys & \multicolumn{10}{|c|}{ in AS-SS } \\
\hline WBC & 0.50 & 0.06 & 0.82 & 1.86 & & & & & & 3.24 \\
\hline W99 & & 0.10 & 1.64 & 2.24 & 0.68 & & & & & 4.66 \\
\hline RTI & & & & 1.06 & & 2.54 & & & & 3.60 \\
\hline PSR & & & & & & & 1.54 & 3.46 & 1.26 & 6.26 \\
\hline Alloys & \multicolumn{10}{|c|}{ in SS } \\
\hline WBC & 0.04 & 0.02 & 0.08 & 0.26 & & & & & & 0.40 \\
\hline W99 & & 0.00 & 0.02 & 0.78 & 0.60 & & & & & 1.40 \\
\hline RTI & & & & 0.92 & & 0.00 & & & & 0.92 \\
\hline PSR & & & & & & & 0.52 & 0.08 & 0.74 & 1.34 \\
\hline
\end{tabular}

Table 5 Average released quantity of elements from metal-ceramic alloys $\left(\mu \mathrm{g} / \mathrm{cm}^{2}\right.$ week)

\begin{tabular}{|c|c|c|c|c|}
\hline Alloys & Elements & in AS-LA & in AS-SS & in $\mathrm{SS}$ \\
\hline \multirow[t]{5}{*}{ WBC } & Co & 4.731 & 3.791 & 0.272 \\
\hline & $\mathrm{Cr}$ & 1.516 & 0.424 & 0.090 \\
\hline & Mo & 8.007 & 3.366 & 0.788 \\
\hline & $\mathrm{Fe}$ & 18.289 & 10.646 & 1.759 \\
\hline & Total & 32.543 & 18.227 & 2.909 \\
\hline \multirow[t]{5}{*}{ W99 } & $\mathrm{Ni}$ & 14.134 & 5.186 & 3.366 \\
\hline & $\mathrm{Cr}$ & 1.728 & 0.788 & 0.000 \\
\hline & Mo & 6.369 & 7.006 & 0.090 \\
\hline & $\mathrm{Fe}$ & 13.557 & 11.191 & 5.641 \\
\hline & Total & 35.788 & 24.171 & 9.097 \\
\hline \multirow[t]{3}{*}{ RTI } & $\mathrm{Ti}$ & 14.649 & 5.489 & 0.000 \\
\hline & $\mathrm{Fe}$ & 8.007 & 4.367 & 3.851 \\
\hline & Total & 22.656 & 9.856 & 3.851 \\
\hline \multirow[t]{4}{*}{ PSR } & $\mathrm{Au}$ & 9.493 & 7.521 & 2.972 \\
\hline & $\mathrm{Pt}$ & 53.351 & 17.591 & 0.667 \\
\hline & In & 19.836 & 5.823 & 1.243 \\
\hline & Total & 82.680 & 30.935 & 4.882 \\
\hline
\end{tabular}




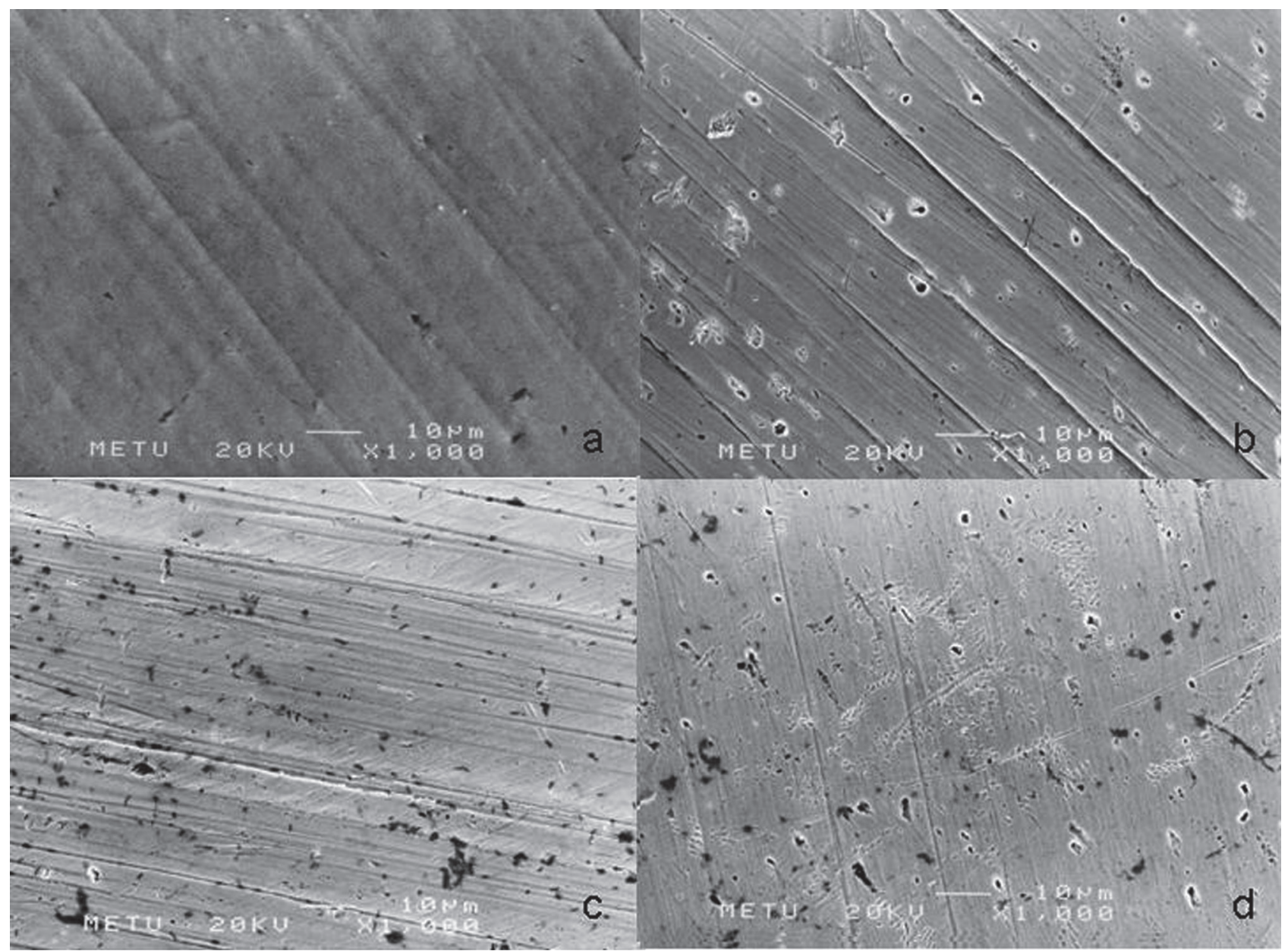

Fig. 5 SEM pictures of WBC alloy: (a) before immersion; (b) after immersion in AS-LA; (c) after immersion in AS-SS; and (d) after immersion in SS.

On ion release per week, ISO 8891:1998 recommended that the maximum quantity released was allowed to be $100 \mu \mathrm{g} / \mathrm{cm}^{2}$ week. Three classes, classes IIII, have been defined based on the quantity released per week. Alloys in class I release $10 \mu \mathrm{g} / \mathrm{cm}^{2}$ week or less, alloys in class II $10-100 \mu \mathrm{g} / \mathrm{cm}^{2}$ week, and alloys in class III $100-1,000 \mu \mathrm{g} / \mathrm{cm}^{2}$ week. In this study, all dental casting alloys immersed in AS-LA solution belonged to class II (Table 5). Alloys WBC, W99, and PSR immersed in AS-SS solution also belonged to class II (Table 5). On the overall, none of the alloys released such a large quantity of metallic ions to induce adverse biological reactions.

\section{SEM analysis}

SEM micrographs of WBC, W99, RTI, and PSR alloys before immersion and after immersion in AS-LA, AS-SS, and SS are shown in Figs. 5-8 respectively. Surface corrosion was observed for all alloy samples, and in particular high acidic effect after immersion in AS-LA solution with $\mathrm{pH}$ 2.3. PSR alloy presented the smoothest surface micrographs.

\section{DISCUSSION}

Ion release and biocompatibility

In the oral environment, the biocompatibility of a dental casting alloy is inextricably linked to its ion release behavior. In living systems, some metals have biological functions. While $\mathrm{Fe}$ is essential in relatively high concentrations, other elements such as $\mathrm{Zn}, \mathrm{Cu}, \mathrm{Ni}$, Co, $\mathrm{Mo}$, and perhaps $\mathrm{Cr}$, are essential in trace amounts for some living systems. At higher concentrations, they can become very toxic. Some metals such as mercury, lead, cadmium, and uranium have no clear biological functions and are toxic even at very low levels.

It is not realistic for all metal-ceramic alloys introduced on the market to be evaluated in both experimental and clinical studies. Clinical trials are time-consuming, expensive, and in some instances inappropriate or unethical. Laboratory tests are an attractive practical alternative in light of the positive correlation between laboratory tests and clinical trials. In this study, four commercially available metal-ceramic dental casting alloys representing different compositions 


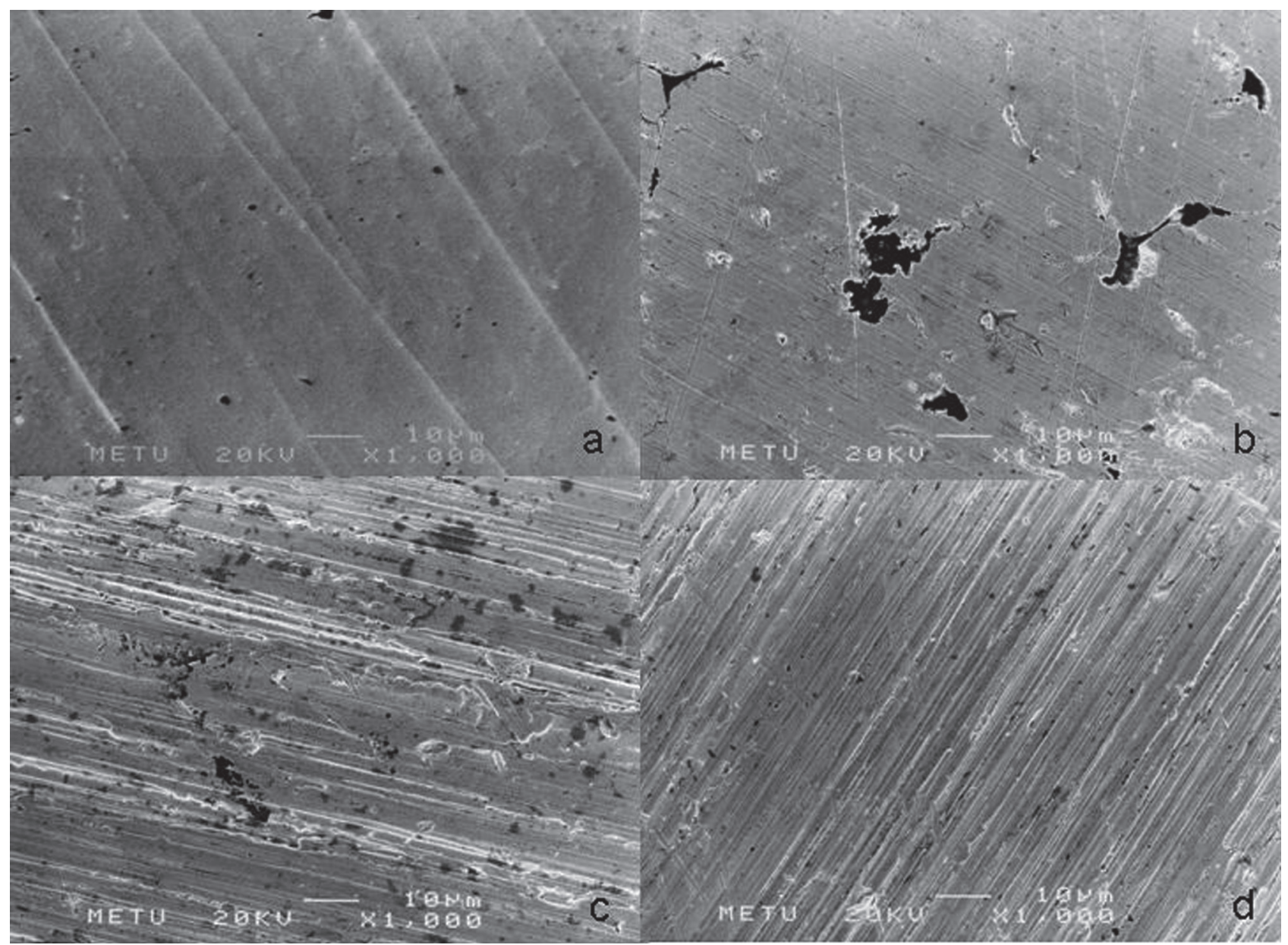

Fig. 6 SEM pictures of W99 alloy: (a) before immersion; (b) after immersion in AS-LA; (c) after immersion in AS-SS; and (d) after immersion in SS.

were selected: WBC (Co-Cr-based alloy), W99 (Ni-Cr-based alloy), RTI (Ti-based alloy), and PSR (high-Au alloy). For a fair assessment of the effect of chemical composition on corrosion resistance and metallic ion release, the four selected alloys were subjected to identical test conditions of being immersed in AS-LA, AS-SS, and SS for a period of 60 days. To simulate the oral temperature, all immersion solutions containing the alloy samples were incubated at $37^{\circ} \mathrm{C}$.

Both nickel and chromium could cause hypersensitivity. Thus, the potential health hazards of these metals and their compounds have been the focus of attention for more than 100 years ${ }^{26)}$. According to Barrett et $a l .{ }^{27)}$, the average dietary intake of $\mathrm{Ni}$ is 200-300 $\mu \mathrm{g} /$ day. The amount of Ni necessary to induce allergy after a single exposure has been calculated to be 0.6-2.5 $\mathrm{mg}^{4)}$. In the present study, quantities of $\mathrm{Ni}$ released from Ni-based alloy W99 in the three different immersion media (Table 5) were markedly below the average dietary intake of $200-300 \mu \mathrm{g} / \mathrm{day}^{26)}$.

Chromium is an essential nutrient of man in amounts of 50-200 mg/day in glucose metabolism. The average dietary intake of $\mathrm{Cr}$ is $280 \mu \mathrm{g} / \mathrm{day}^{26)}$. However, chromate salts - which result from the corrosion of base metal alloys- could cause skin sensitivity and dermatitis. Incidence of $\mathrm{Cr}$ allergy was reported to be $10 \%$ in males and $3 \%$ in females. The estimated lethal dose for $\mathrm{Cr}$ in humans is about $50-70 \mathrm{mg} / \mathrm{kg}$ body weight ${ }^{26)}$. In the present study, quantities of $\mathrm{Cr}$ released from WBC and W99 (Table 5) were also markedly below the average dietary intake of $280 \mu \mathrm{g} / \mathrm{day}^{26)}$.

\section{Factors related to ion release}

Intraoral corrosion is a very complex process. Factors that affect corrosion and metal ion release run the gamut from composition and metallurgical state, combinations within a construct, surface conditions, mechanical aspects of function, to the local and systemic host environment ${ }^{28)}$.

1. Chemical composition of alloy

Starting with an alloy's chemical composition, some alloying elements are known by their lability more than other elements. Some alloying combinations may result in synergistic effects which alter the elements' lability 


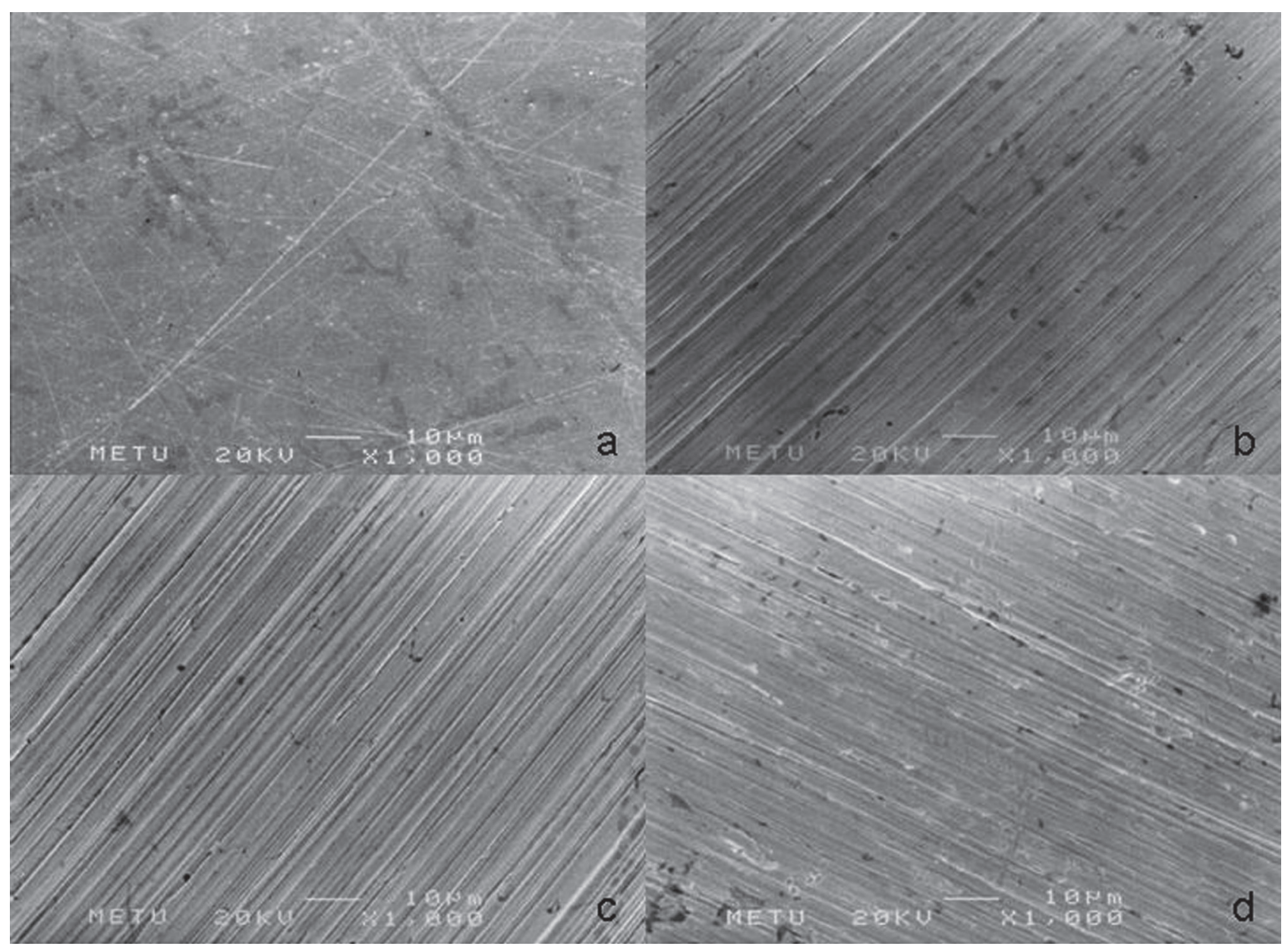

Fig. 7 SEM pictures of RTI alloy: (a) before immersion; (b) after immersion in AS-LA; (c) after immersion in AS-SS; and (d) after immersion in SS.

and thus increase or decrease the ion release rate $^{2,3,5,6,22,28,29)}$. Ni, Cr, Mo, and Co had a decreasing effect on the corrosion rate of base metal alloys ${ }^{5,17,24,30-32)}$, whereas Fe had an increasing effect ${ }^{10,24)}$. The ion release results of WBC, W99, and RTI in the present study (Figs. 1-3) showed similar findings.

A survey of published literature showed that $\mathrm{Cr}, \mathrm{Mo}$, manganese (Mn), and tungsten (W) were alloy elements with strong beneficial influence on the corrosion resistance of Ni-based and/or Co-Cr alloys ${ }^{33,34)}$. Yfantis et $a l{ }^{34)}$ suggested that the enhanced corrosion behavior of WBC was due to $\mathrm{W}$ addition and its relatively high $\mathrm{Cr}$ content. Bilhan et al. ${ }^{33)}$ showed that Mo and Mn additions to Ni-based alloys improved their corrosion resistance, and that alloys with a high Mo content had better corrosion properties than those with a low level. Al-Hiyasat et $a l .^{31)}$ reported that for ion release from $\mathrm{Ni}-\mathrm{Cr}$ and Co-Cr alloys used in their study, Cr release was very low when compared with Mo and Ni ions; in most cases, $\mathrm{Cr}$ release was below the detection limit. Similarly, other studies have reported that $\mathrm{Cr}$ release was consistently low even in different immersion solutions ${ }^{8,17,34)}$. In the present study, $\mathrm{Cr}$ release from WBC and W99 alloys was indeed very low in all immersion solutions, especially when compared with the release of $\mathrm{Co}, \mathrm{Mo}, \mathrm{Fe}$, and $\mathrm{Ni}$ ions.

A survey of published literature also showed that an alloy was protected against corrosion when its $\mathrm{Cr}$ content was higher than $16 \mathrm{wt} \%^{5,22,30,32)}$. Pfeiffer et al. ${ }^{5)}$ reported that when the content of $\mathrm{Cr}$ in an alloy was lower than 16 wt\%, Ni release from the alloy became higher. However, when $\mathrm{Cr}$ content was above $20 \mathrm{wt} \%$, Strietzel and Viohl ${ }^{30}$ ) reported that the alloy exhibited long-term corrosion resistance. Molina et al..$^{22)}$ reported that a complex stable passive oxide layer which provided adequate corrosion resistance was formed on the surfaces of $\mathrm{Ni}-\mathrm{Cr}$ alloys containing 16-22\% $\mathrm{Cr}$ and 9-14\% Mo; on the contrary, an Ni-Cr-Mo alloy with a low $\mathrm{Cr}$ and Mo content was associated with a high corrosion rate and susceptibility to accelerated corrosion processes. Similarly, Manaranche and Hornberger ${ }^{32}$ reported that when the content of $\mathrm{Cr}$ was more than $18 \mathrm{wt} \%$, passivation of the alloy surface took place and the impervious passive film protected the alloy against corrosion. In the present 


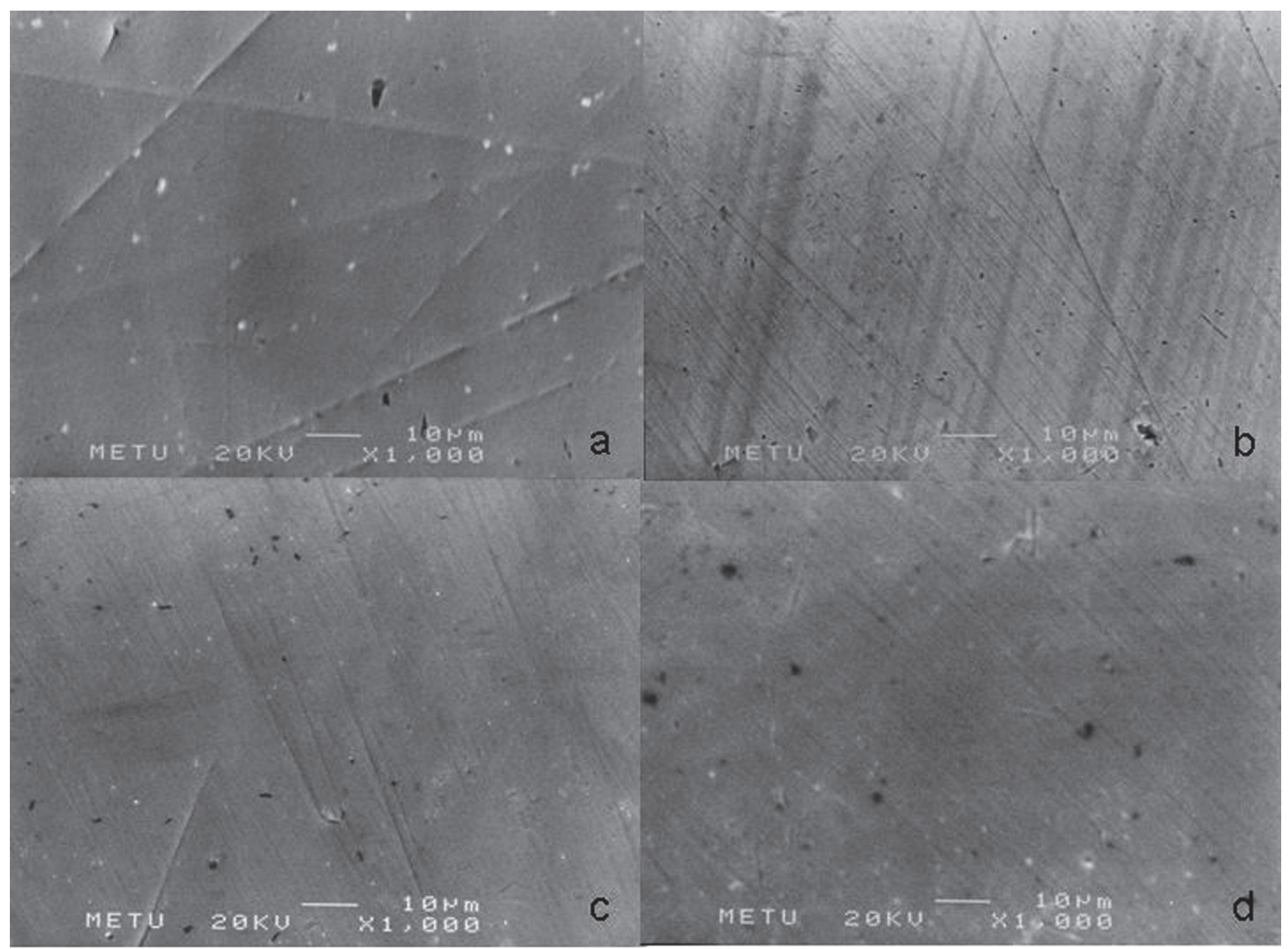

Fig. 8 SEM pictures of PSR alloy: (a) before immersion; (b) after immersion in AS-LA; (c) after immersion in AS-SS; and (d) after immersion in SS.

study, the contents of $\mathrm{Cr}$ in WBC and W99 were 26 wt\% and 22.5 wt\% respectively (Table 1 ). With a higher $\mathrm{Cr}$ content in WBC alloy, its corrosion resistance was expectedly higher than that of W99. As seen in Figs. 1-2 and Table 4, the release of Co and Mo ions from WBC alloy was lower than the release of $\mathrm{Ni}$ and $\mathrm{Mo}$ ions from W99 alloy.

Although Co-Cr based alloys are known to have excellent corrosion resistance ${ }^{4,34)}$, Reclaru et al. ${ }^{35}$ ) reported that the presence of precious metals (Au, Pt, $\mathrm{Ru}$ ) deteriorated the corrosion resistance of $\mathrm{Co}-\mathrm{Cr}$ dental alloys in a significant way - a fitting and resounding indication of the influence of chemical composition on corrosion behavior.

2. Carbon content and microstructure

Of the three thermodynamically stable forms of chromium carbides, $\mathrm{Cr}_{23} \mathrm{C}_{6}$ is the most stable compound. Carbide stability is markedly temperature-dependent, with markedly higher concentrations of $\mathrm{C}$ and $\mathrm{Cr}$ formed in acidic environments. This means that in an acidic medium, $\mathrm{Cr}_{23} \mathrm{C}_{6}$ compound easily forms ${ }^{36)}$. However, if $\mathrm{Cr}_{23} \mathrm{C}_{6}$ is formed in the microstructures of $\mathrm{Co}-\mathrm{Cr}$ and
$\mathrm{Ni}-\mathrm{Cr}$ alloys in acidic media, then $\mathrm{Cr}$ is no longer available to provide corrosion resistance. This means that $\mathrm{Cr}_{23} \mathrm{C}_{6}$ formation must be prevented in dental casting alloys.

In WBC alloy, the content of $\mathrm{C}$ was $0.02 \mathrm{wt} \%$ (Table 1). Extra low $\mathrm{C}$ levels, preferably below $0.03 \mathrm{wt} \%$, are a highly recommended means to prevent $\mathrm{Cr}_{23} \mathrm{C}_{6}$ formation in casting alloys. The theory is that carbides will not form if the $\mathrm{C}$ level is below some critical value. Nonetheless, some carbides still form at low $\mathrm{C}$ levels and in properly heat-treated materials, but they are few and far between.

In W99 alloy, where the content of $\mathrm{C}$ was $0.5 \mathrm{wt} \%$, the use of carbon stabilizing elements such as niobium $(\mathrm{Nb} ; 1 \mathrm{wt} \%$ in W99 alloy, Table 1) was the preferred means. Alloys which contain these elements are specially heat-treated to form niobium carbides $\left(\mathrm{Nb}_{2} \mathrm{C}\right)$. The $\mathrm{C}$ element then becomes no longer available to form $\mathrm{Cr}_{23} \mathrm{C}_{6}$, leaving $\mathrm{Cr}$ free and available to provide corrosion resistance.

3. Metallurgical state and surface conditions

Many factors change the final properties of a dental 
metal-ceramic alloy, such as the casting process, heating and cooling processes during casting, and the porcelainfused-to-metal firing process ${ }^{11)}$. These processes may alter the metallurgical state, surface oxides, and corrosion properties of the alloy depending on its chemical composition. A multiphase (heterogeneous) alloy is more prone to corrosion than a monophase or single-phase (homogeneous) alloy, due to a galvanic effect between areas of different compositions inside the alloy $^{1,13)}$.

In light of these processes involved in alloy manufacturing, which may cause differences in the final properties among alloys, it is therefore important to use commercial alloy systems in research studies to facilitate comparison of results and finding among studies and if clinical relevance is desired. For these reasons, four commercial metal-ceramic alloys were selected for investigation in this study.

4. Local and systemic host environment

Ion release of dental alloys is also affected by environmental conditions, such as the acidity and composition of the surrounding electrolyte $\mathrm{e}^{3,5,10,20,22,24,37)}$. An acidic environment (low $\mathrm{pH}$ ) causes the electrochemical equilibrium to shift towards unfavorable conditions that lower generally the polarization resistance and increase the release of ions from alloys $2,3,5,6,10,19-21,24,28,29,37)$. The stability of Ni-based alloys has been shown to be significantly reduced when placed in more acidic environments, causing an increase in metal ion release $\mathrm{e}^{5)}$. Likewise, Co ion release from base metal alloys was significantly affected by low $\mathrm{pH}^{7)}$. In a study by Strietzel and $\mathrm{Viohl}^{30}$, it was concluded that when $\mathrm{pH}$ conditions became more acidic, the amount of ion release from non-precious and palladium alloys became higher (Figs. $1-2)$.

Can et al. ${ }^{37)}$ compared the ion release behaviors of a Ni-Cr alloy using artificial saliva (AS) and a cell culture medium. They reported that ion release was lower in the cell culture medium. In light of the ion release results obtained in previous researches which used cell culture media ${ }^{1,37)}$, AS and saline solutions were used in the present study instead of a cell culture medium. For Vrijhoef et $a l .^{3)}$, a $0.9 \%$ saline solution (SS) of $\mathrm{pH} 5.3$ was selected as the immersion medium to investigate the corrosion of ferromagnetic alloys used for magnetic retention of overdentures because it is an aggressive solution without inhibitory action. In the present study, the $\mathrm{pH}$ value of SS was adjusted to 7.3 so that it would not act as an aggressive solution. Instead, AS solutions with pH 2.3 (AS-LA) and pH 6.5 (AS-SS) were selected as the aggressive solutions to investigate the ion release of casting alloys. As shown in Figs. 1-4, ion release of all the tested dental casting alloys was found to be $\mathrm{pH}$-dependent: markedly fewer ions were detected in SS ( $\mathrm{pH}$ 7.3) than in AS-LA ( $\mathrm{pH}$ 2.3) and AS-SS ( $\mathrm{pH}$ 6.5).

Natural saliva is an extremely complex system with numerous constituents and variables according to the time of day. Thus, exact duplication is impossible ${ }^{34}$. Covington et al. ${ }^{38)}$ studied the release of $\mathrm{Ni}$ and $\mathrm{Be}$ ions from base-metal dental casting alloys in artificial saliva
(AS) with different $\mathrm{pH}$ values. They found that decreased $\mathrm{pH}$ and increased immersion period up to 120 days resulted in enhanced $\mathrm{Ni}$ and Be release. In the present study, AS-LA with $\mathrm{pH} 2.3$ was used to examine the corrosion behavior of alloys under the worst-case condition. Indeed, highest ion release results were obtained in AS-LA immersion for all metal-ceramic alloys. In particular, $\mathrm{Pt}$ ion release ranked the highest after 60 days of immersion in AS-LA solution. In the context of the present study, this caused PSR alloy to exhibit the highest ion release result among all the tested alloys. Nonetheless, 7-day ion release results of Au-Pt-based PSR alloy in AS-LA immersion (Table 5) were consistent with the results of an Au-Pt-based alloy (V-Gnathos Plus) of a previous study which concluded that its corrosion resistance was acceptable ${ }^{32)}$.

In the present study, the presence of $\mathrm{Cl}$ ions in all the three immersion solutions rendered them as electrolytic media. Increase in $\mathrm{Cl}$ ion and decrease in $\mathrm{pH}$ increased the aggressiveness of the electrolyte ${ }^{36,39)} . \mathrm{Cl}$ ion from $\mathrm{NaCl}$ at $\mathrm{pH} 2.3$ with $\mathrm{H}$ ion acted as $\mathrm{HCl}$ solution on $\mathrm{Fe}$ ion. Consequently, elemental $\mathrm{Fe}$ was released from the alloys into the immersion solutions as Fe ion (Figs. 1-3). Despite the low Fe content in the alloys, its extremely high affinity resulted in the release of a large quantity of $\mathrm{Fe}$ ion.

Proteins in immersion solutions have an effect on metallic corrosion, by virtue of the formation of metalprotein complexes on alloy surfaces ${ }^{28)}$. Mezger et al. ${ }^{20)}$ evaluated the effect of mucin (an organic compound) on the corrosion behavior of dental casting alloys at different $\mathrm{pH}$ levels. Mucin hardly exerted any influence at a low $\mathrm{pH}$ value; however, it seemed to act as a cathodic inhibitor at a high $\mathrm{pH}$ value. Based on this finding ${ }^{20)}$, mucin was omitted from AS solutions in this study as its presence in either AS-LA or AS-SS with low $\mathrm{pH}$ values would be inconsequential. Compared with immersion in SS alone, the presence of proteins in SS was found to enhance the release of $\mathrm{Ag}, \mathrm{Cu}, \mathrm{Pd}$, and $\mathrm{Zn}$ ions - but the opposite was reported for $\mathrm{Ni}-\mathrm{Cr}$ alloy. In a recent study by Bilhan et $a l .{ }^{33)}$ which investigated the effect of salivary proteins (mucin, IgA, urea, and lysozyme) on the corrosion of dental amalgam, pure Ti, Co-Cr-Mo and $\mathrm{Ni}-\mathrm{Cr}-\mathrm{Mo}$ alloys, it was revealed that Ni-Cr-Mo and dental amalgam alloys were highly susceptible to corrosion whereas Co-Cr-Mo alloy and pure Ti exhibited passive behavior. Salivary proteins appeared to enhance passive film formation on Ti surface, thereby inhibiting corrosion. Although no salivary proteins were selected in the current study, the corrosion behaviors of pure $\mathrm{Ti}$, Co-Cr-Mo and Ni-Cr-Mo alloys observed by Bilhan et $a l .{ }^{33)}$ agreed with the present study.

\section{Corrosion measurement methods}

All dental cast alloys release metal ions - with varying amounts and of varied types — into the oral environment which have the potential to interact with oral tissues ${ }^{28)}$. Interestingly, the amounts of metal ions released do not reflect their relative weight contents in an alloy's composition $^{28)}$. The conventional method to determine 
corrosion rates is the weight loss method which requires long-term exposure. The primary advantage of this test method is that it resembles the real application. The main disadvantage is that it is difficult to keep the variables under control throughout the entire exposure period.

Alternatively, electrochemical methods can be used to characterize the corrosion properties of metals and metal alloys. In the present study, AAS was used to analyze ion release. Unlike calirometric analysis and ultraviolet spectrophotometry, AAS can accurately and rapidly measure ion concentrations to levels below 1 $\mathrm{ppm}^{26)}$. For a complete picture of the corrosion behavior of the four selected commercial dental alloys, a two-pronged strategy was used in this study: AAS determination of ion release at different $\mathrm{pH}$ values (Figs. 1-4) and SEM analysis of sample surfaces before and after immersion in different $\mathrm{pH}$ media (Figs. 5-8).

According to Wataha and Malcolm ${ }^{40)}$, SEM analysis revealed no differences in the surface appearances of alloys up to $\times 1,000$ magnification before and after a 30-day exposure to a cell culture medium. In the present study, however, WBC and W99 samples immersed in AS-LA and AS-SS showed noticeable differences in SEM micrographs acquired at the same magnification (Figs. $5(\mathrm{~b})-(\mathrm{c})$ and $6(\mathrm{~b})-\mathrm{c})$ ).

\section{Corrosion behavior of $\mathrm{Ti}$}

Compared with other non-noble dental alloys, pure Ti reportedly had better corrosion properties and biocompatibility ${ }^{14,24,30)}$. In this study, RTI alloy showed moderate ion release in all the immersion solutions which could be attributed to a passive oxide film covering the titanium alloy surface.

In a study by Cheng et al. ${ }^{16)}$, all the experimentally prepared Ti alloys showed excellent corrosion resistance without any breakdown in Hanks' solution at $37^{\circ} \mathrm{C}$. Hanks' solution has a high concentration of $\mathrm{Cl}$ ions, and $\mathrm{Ti}$ and $\mathrm{Ti}$ alloys assume excellent corrosion resistance under the influence of $\mathrm{Cl}$ ions. In the present study, the largest amount of $\mathrm{Ti}$ was released from RTI in acidic AS-LA solution while no Ti was released when immersed in SS.

Taira et al. ${ }^{21)}$ studied the mechanical properties and corrosion resistance of various cast Ti alloys. They concluded that cast pure $\mathrm{Ti}$ had mechanical properties similar to those of type 4 (extra hard) Au alloy. As for cast Ti alloys, they were immune to corrosion attacks in the oral environment - even under highly acidic surroundings. The strong passivity trend exhibited by all the cast $\mathrm{Ti}$ alloys ${ }^{21)}$ agreed with the RTI alloy results of the present study.

Corrosion behavior of noble metals and alloys

High-Au alloys are highly corrosion-resistant ${ }^{14,29)}$. They also exhibited the best clinical and in vivo results against tarnish ${ }^{29,39)}$, and it was found that patient-related factors had as much influence on the corrosion resistance as the microstructure of the alloy. Wirz et al. ${ }^{29)}$ conducted both in vitro and in vivo experiments to evaluate and compare ion release from Au-based, Co-based, and Ni-based dental casting alloys. Findings of both in vitro and in vivo studies supported each other. The results of PSR, WBC, and W99 alloys in the present study were also consistent with their in vitro results ${ }^{29)}$.

Using a cell culture medium as the immersion medium, Wataha et al. ${ }^{15)}$ reported absence of $\mathrm{Au}$ ion release from high-noble alloys. However, in the present study, Au ions were detected in all the three immersion media. Using AS as the immersion medium and with X-ray diffraction analysis, Brune et al. ${ }^{14)}$ detected considerable amounts of Au released from the $\mathrm{Au}$ alloys but Ti corrosion products could not be assessed in view of faint activity levels. In a recent study on ion release using experimental Au-Pt-based metal-ceramic alloys immersed in deionized water and a commercial soft drink $^{10)}$, similar ion release results were reported for the corresponding $\mathrm{pH}$ levels.

In another study ${ }^{32}$ ) which evaluated the corrosion resistance of dental alloys using chemical and electrochemical corrosion tests, Au-Pt alloys were found to release a higher quantity of ions compared with other precious alloys, but lower than Ni-Cr alloys. Using both $\mathrm{AS}$ and SS as the immersion media and evaluation by means of microphotography and SEM, Johansson et al. ${ }^{39}$ ) reported that $\mathrm{Cu}$-based and Be-containing $\mathrm{Ni}$ alloys showed more tarnish and corrosion than did $\mathrm{Ni}$ and $\mathrm{Au}$ alloys - findings similar to those of W99 and PSR alloys in this study (Figs. 6 and 8).

In the absence of detailed data on corrosion for an alloy, use of high-noble and noble alloys of single-phase microstructure will minimize biological risks because ion release from these alloys is lower. However, detailed ion release data are always preferred because even with similar compositions, each alloy exhibits somewhat different ion release behaviors ${ }^{6}$.

\section{CONCLUSIONS}

Within the limitations of this study, the following conclusions were drawn:

1. Results of in vitro corrosion studies depend on instrumentation and experimental variables. Differences in study designs and chemical factors make comparisons between corrosion studies more difficult.

2. The in vitro corrosion behavior of WBC alloy was better than that of W99 alloy. Total ion release of W99 alloy after 60-day immersion in AS-LA solution was $9.92 \mathrm{wt} \%$, approximately twice that of WBC alloy (5.26 wt\%). Nevertheless, both alloys were considered as adequately corrosionresistant.

3. The in vitro corrosion properties of W99 and WBC alloys were dependent on their chemical compositions. W99 contained $22.5 \% \mathrm{Cr}$ and $9.5 \%$ Mo, and its high $\mathrm{Cr}$ and Mo content augmented its resistance to corrosion attacks.

4. Results of this in vitro corrosion study showed that the four selected commercial alloys were well 
suited for dental usage. As a rule of thumb, prudence dictates that dental practitioners should know the complete composition of each alloy used and use only alloys that show the lowest ion release rate.

\section{ACKNOWLEDGMENTS}

This research was financially supported by the Gazi University Research Fund (03/97-02), Ankara, Türkiye.

\section{REFERENCES}

1) Wataha JC, Craig RG, Hanks CT. The release of elements of dental casting alloys into cell-culture medium. J Dent Res 1991; 70: 1014-1018.

2) Niemi L, Minni E, Ivaska A. An electrochemical and multispectroscopic study of corrosion of $\mathrm{Ag}-\mathrm{Pd}-\mathrm{Cu}-\mathrm{Au}$ alloys. J Dent Res 1986; 65: 888-891.

3) Vrijhoef MMA, Mezger PR, Van der Zel JM, Greener EH. Corrosion of ferromagnetic alloys used for magnetic retention of overdentures. J Dent Res 1987; 66: 1456-1459.

4) Geis-Gerstorfer J, Sauer KH, Passler K. Ion release from Ni-Cr-Mo and Co-Cr-Mo casting alloys. Int $\mathrm{J}$ Prosthodont 1991; 4: 152-158.

5) Pfeiffer $P$, Schwickerath $H$. Nickelabgabe von Dentallegierungen in Abhangigkeit vom pH-Wert der Korrosionslösung. Dtsch Zahnarztl Z 1991; 46: 753-756.

6) Wataha JC. Biocompatibility of dental casting alloys: a review. J Prosthet Dent 2000; 83: 223-234.

7) Denizoglu S, Duymus ZY, Akyalcin S. Evaluation of ion release from two base-metal alloys at various $\mathrm{pH}$ levels. J Int Med Res 2004; 32: 33-38.

8) Bumgardner JD, Lucas LC. Cellular response to metallic ions released from nickel-chromium dental alloys. J Dent Res 1995; 74: 1521-1527.

9) Jones SB, Taylor RL, Colligon JS, Johnson D. Effect of element concentration on nickel release from dental alloys using a novel ion beam method. Dent Mater 2010; 26: 249-256.

10) Johnson A, Shiraishi T, Al-Salehi SK. Ion release from experimental Au-Pt-based metal-ceramic alloys. Dent Mater 2010; 26: 682-687.

11) Wylie CM, Shelton RM, Fleming GJP, Davenport AJ. Corrosion of nickel-based dental casting alloys. Dent Mater 2007; 23: 714-723.

12) Elshahawy W, Watanabe I, Koike M. Elemental ion release from four different fixed prosthodontic materials. Dent Mater 2009; 25: 976-981.

13) Strub JR, Eyer CS, Sarkar NK. Heat treatment, microstructure and corrosion of a low-gold casting alloy. J Oral Rehabil 1986; 13: 521-528.

14) Brune D, Evje D, Melsom S. Corrosion of gold alloys and titanium in artificial saliva. Scand J Dent Res 1982; 90: 168-171.

15) Wataha JC, Malcolm CT, Hanks CT. Correlation between cytotoxicity and elements released by dental casting alloys. Int J Prosthodont 1995; 8: 9-14.

16) Cheng WW, Ju CP, Chern Lin JH. Structure, castability and mechanical properties of commercially pure and alloyed titanium cast in graphite mould. J Oral Rehabil 2007; 34 : 528-540.

17) Bumgardner JD, Lucas LC. Surface analysis of nickelchromium dental alloys. Dent Mater 1993; 9: 252-259.

18) Karov J, Hinberg I. Galvanic corrosion of selected dental alloys. J Oral Rehabil 2001; 28: 212-219.

19) Sun D, Monaghan P, Brantley WA, Johnston WM.
Potentiodynamic polarization study of the in vitro corrosion behavior of 3 high-palladium alloys and a gold-palladium alloy in 5 media. J Prosthet Dent 2002; 87: 86-93.

20) Mezger PR, van't Hof MA, Vrijhoef MMA, Gravenmade EJ, Greener EH. Effect of mucin on the corrosion behavior of dental casting alloys. J Oral Rehabil 1989; 16: 589-596.

21) Taira M, Moser JB, Greener EH. Studies of Ti alloys for dental castings. Dent Mater 1989; 5: 45-50.

22) Molina C, Nogués L, Martinez-Gomis J, Peraire M, Salsench J, Sevilla P, Gil FJ. Dental casting alloys behaviour during power toothbrushing with toothpastes of various abrasivities. Part II: corrosion and ion release. J Mater Sci Mater Med 2008; 19: 3015-3019.

23) ISO 10271 Standard. Dental metallic materials-corrosion test methods. 1st ed, Switzerland: ISO Geneva; 2001.

24) Bayramoglu G, Alemdaroglu T, Kedici S, Aksut AA. The effect of $\mathrm{pH}$ on the corrosion of dental metal alloys. J Oral Rehabil 2000; 27: 563-575.

25) ISO 8891. For the dental casting alloys with noble metal content of $25 \%$ up but not including $75 \%$. Switzerland: ISO Geneva; 1998.

26) Bhaskar V, Subba Reddy VV. Biodegradation of nickel and chromium from space maintainers: an in vitro study. J Indian Soc Pedod Prev Dent 2010; 28: 6-12.

27) Barrett RD, Bishara SE, Quinn JK. Biodegradation of orthodontic appliances. Part I. Biodegradation of nickel and chromium in vitro. Am J Orthod Dentofacial Orthop 1993; 103: 8-14

28) Schmalz G, Garhammer P. Biological interactions of dental cast alloys with oral tissues. Dent Mater 2002; 18: 396-406.

29) Wirz J, Haefeli D, Schmidli F. Aufbrennlegierungen im Korrosionstest. Quintessenz 1993; 44: 75-84.

30) Strietzel R, Viohl J. Das Langzeit-Korrosionsverhalten von NEM-, Palladiumlegierungen und Titan in künstlichem Speichel. Dtsch Zahnarztl Z 1992; 47: 535-538.

31) Al-Hiyasat AS, Bashabsheh OM, Darmani H. Elements released from dental casting alloys and their cytotoxic effects. Int J Prosthodont 2002; 15: 473-478.

32) Manaranche $C$, Hornberger $H$. A proposal for the classification of dental alloys according to their resistance to corrosion. Dent Mater 2007; 23: 1428-1437.

33) Bilhan H, Bilgin T, Cakir AF, Yuksel B, Von Fraunhofer JA The effect of mucine, IgA, urea, and lysozyme on the corrosion behavior of various non-precious dental alloys and pure titanium in artificial saliva. J Biomater Appl 2007; 22: 197-221.

34) Yfantis C, Yfantis D, Anastassopoulou J, Theophanides T. Analytical and electrochemical evaluation of the in vitro corrosion behavior of nickel-chrome and cobalt-chrome casting alloys for metal-ceramic restorations. Eur J Prosthodont Res Dent 2007; 15: 33-40.

35) Reclaru L, Lüthy H, Eschler PY, Blatter A, Susz C. Corrosion behaviour of cobalt-chromium dental alloys doped with precious metals. Biomaterials 2005; 26: 4358-4365.

36) Craig RG, Powers JM, Sakaguchi RL. Craig's restorative dental materials. 12th ed, St. Louis: Mosby Elsevier Inc; 2006. pp. 359-410.

37) Can G, Akpinar G, Aydin A. The release of elements from dental casting alloy into cell-culture medium and artificial saliva. Eur J Dent 2007; 1: 86-90.

38) Covington JS, McBride MA, Slagle WF, Disney AL. Quantization of nickel and beryllium leakage from base metal casting alloys. J Prosthet Dent 1985; 54: 127-136.

39) Johansson BI, Lemons JE, Hao SQ. Corrosion of dental copper, nickel, and gold alloys in artificial saliva and saline solutions. Dent Mater 1989; 5: 324-328.

40) Wataha JC, Malcolm CT. Effect of alloy surface composition on release of elements from dental casting alloys. J Oral Rehabil 1996; 23: 583-589. 